Article

\title{
Colloidal and Deposited Products of the Interaction of Tetrachloroauric Acid with Hydrogen Selenide and Hydrogen Sulfide in Aqueous Solutions
}

\author{
Sergey Vorobyev ${ }^{1}$, Maxim Likhatski ${ }^{1}$, Alexander Romanchenko ${ }^{1}$, Nikolai Maksimov ${ }^{1}$, \\ Sergey Zharkov ${ }^{2,3}$, Alexander Krylov ${ }^{2}$ (i) and Yuri Mikhlin ${ }^{1, *(1)}$ \\ 1 Institute of Chemistry and Chemical Technology of the Siberian Branch of the Russian Academy of Sciences, \\ Krasnoyarsk 660036, Russia; yekspatz@yandex.ru (S.V.); lixmax@icct.ru (M.L.); romaas82@mail.ru (A.R.); \\ burmakina@ksc.krasn.ru (N.M.) \\ 2 Kirensky Institute of Physics of the Siberian Branch of the Russian Academy of Sciences, \\ Krasnoyarsk 660036, Russia; zharkov@iph.krasn.ru (S.Z.); shusy@iph.krasn.ru (A.K.) \\ 3 Electron Microscopy Laboratory, Siberian Federal University, Krasnoyarsk 660041, Russia \\ * Correspondence: yumikh@icct.ru; Tel.: +7-391-205-1928
}

Received: 11 October 2018; Accepted: 29 October 2018; Published: 31 October 2018

\begin{abstract}
The reactions of aqueous gold complexes with $\mathrm{H}_{2} \mathrm{Se}$ and $\mathrm{H}_{2} \mathrm{~S}$ are important for transportation and deposition of gold in nature and for synthesis of AuSe-based nanomaterials but are scantily understood. Here, we explored species formed at different proportions of $\mathrm{HAuCl}_{4}$, $\mathrm{H}_{2} \mathrm{Se}$ and $\mathrm{H}_{2} \mathrm{~S}$ at room temperature using in situ UV-vis spectroscopy, dynamic light scattering (DLS), zeta-potential measurement and ex situ Transmission electron microscopy (TEM), electron diffraction, X-ray diffraction (XRD), X-ray photoelectron spectroscopy (XPS), and Raman spectroscopy. Metal gold colloids arose at the molar ratios $\mathrm{H}_{2} \mathrm{Se}\left(\mathrm{H}_{2} \mathrm{~S}\right) / \mathrm{HAuCl}_{4}$ less than 2. At higher ratios, pre-nucleation "dense liquid" species having the hydrodynamic diameter of $20-40 \mathrm{~nm}$, zeta potential $-40 \mathrm{mV}$ to $-50 \mathrm{mV}$, and the indirect band gap less than $1 \mathrm{eV}$ derived from the UV-vis spectra grow into submicrometer droplets over several hours, followed by fractional nucleation in the interior and coagulation of disordered gold chalcogenide. XPS found only one $\mathrm{Au}^{+}$site $\left(\mathrm{Au} 4 \mathrm{f}_{7 / 2}\right.$ at $\left.85.4 \mathrm{eV}\right)$ in deposited AuSe, surface layers of which partially decomposed yielding $\mathrm{Au}^{0}$ nanoparticles capped with elemental selenium. The liquid species became less dense, the gap approached $2 \mathrm{eV}$, and gold chalcogenide destabilized towards the decomposition with increasing $\mathrm{H}_{2} \mathrm{~S}$ content. Therefore, the reactions proceed via the non-classical mechanism involving "dense droplets" of supersaturated solution and produce AuSe ${ }_{1-x} \mathrm{~S}_{\mathrm{x}} / \mathrm{Au}$ nanocomposites.
\end{abstract}

Keywords: gold selenide; gold sulfoselenide; colloids; nanoparticles; nucleation; liquid intermediates; deposition

\section{Introduction}

Mixed silver-gold sulfides and selenides, including nanoparticulate ones, have attracted intense interest as minerals and natural sources of precious metals [1-14] and due to high ionic conductivity, tunable optical characteristics, thermoelectric and other properties promising for materials applications [15-19]. Gold chalcogenides, in particular gold selenide, are much less examined, despite aqueous Au chalcogenide-derived complexes play the crucial role as carriers of gold in hydrothermal fluids and brines (e.g., [20-25] and references therein), and AuSe, $\mathrm{Au}(\mathrm{Se}, \mathrm{S})$ and $\mathrm{Au}(\mathrm{Te}, \mathrm{Se}, \mathrm{S})$ phases in intergrowths with native gold have been found in the high-sulfidation epithermal deposits formed from acidic fluids[14]. Solid gold sulfide $\mathrm{Au}_{2} \mathrm{~S}$ is metastable $[2,5,26,27]$. Gold selenide that is the only thermodynamically stable compound in the binary Au-Se system $[3,11,28-37]$ has two 
crystallographic modifications $\alpha$-AuSe and $\beta$-AuSe, which crystallize in the monoclinic space group $\mathrm{C} 2 / \mathrm{m}$ with different lattice constants. In both structures, a half of Au atoms are in a square-planar coordination to four Se atoms, and the others are linearly bound to two Se neighbors. Rabenau and Schulz [31] and then other authors [34,35] have assumed that the gold in the first sites is $\mathrm{Au}^{3+}$, while $\mathrm{Au}^{+}$is located in the linear environment, and each Se atom is linked with one $\mathrm{Au}^{+}$and two $\mathrm{Au}^{3+}$ cations. On the other hand, X-ray absorption spectroscopy [36] and the theoretical calculations [37] have found fully occupied $\mathrm{Au} 5 \mathrm{~d}$ bands and therefore only monovalent $\mathrm{Au}^{+}$atoms.

It is known from chemistry textbooks (for example [38]) that direct interaction between aqueous gold complexes and selenide ions results in precipitation of unstable gold selenides with unclear compositions. Preparation of nanoscale materials containing gold selenide have been described in a few publications [17,39-45]. Nath and co-workers [39] have synthesized "AuSe nanoalloys" via fusion of elemental $\mathrm{Au}$ and Se nanoparticles in a micellar solution, typically with an excess of $\mathrm{Au}$ NPs. Prokeš et al. [40] have used mixed dispersions of gold nanoparticles and elemental selenium, or Se powder suspended in $\mathrm{HAuCl}_{4}$ solutions in various proportions as precursors for laser ablation, and detected in gas phase, by using mass-spectrometry, numerous gold-selenide nanoclusters $\mathrm{Au}_{\mathrm{m}} \mathrm{Se}_{\mathrm{n}}$ leaning to compositions with $\mathrm{Au} / \mathrm{Se}=2$ and $\mathrm{Au} / \mathrm{Se}=1$. Machogo et al. [42] have recently reported the preparation of AuSe nanostructures mixed with metallic nanogold and unreacted Se by the reaction of $\mathrm{HAuCl}_{3} \cdot 3 \mathrm{H}_{2} \mathrm{O}$ with elemental Se in oleylamine. It has been found in several studies aimed at synthesis of hybrid nanostructures that gold commonly deposits onto metal selenide nanoparticles in elemental form [43-45]. Particularly, Cueva et al. [45] have concluded from X-ray photoelectron spectroscopy (XPS) analysis that the shells deposited on CdSe NPs are most probably composed of AuSe or $\mathrm{AuSeCl}$, which are instable and transform into dot-shaped $\mathrm{Au}^{0}$ particles under the electron beam in Transmission electron microscopy (TEM). Several studies on adsorption of selenium [46,47] and alkylselenides on gold and Au NPs [48,49] have revealed no AuSe phases and, for example, demonstrated that alkylselenides replace alkylsulfides due to favored Au-Se bonding.

The products of the reaction of sulfide ions with gold tetrachloride depend on the initial ratio of the reagents [50-55]. Metallic Au NPs emerging at the molar ratios from 0.5 to 1.5 show a second localized surface plasmon resonance (LSPR) in the near-infrared region, which has been suggested to assign to gold-sulfide/gold core/shell particles [50], aggregation of gold nanoparticles [54], or, and this is most likely, to longitudinal plasmon resonance in non-spherical Au NPs [55]. Gold sulfide is the main final product at the $\mathrm{Na}_{2} \mathrm{~S} / \mathrm{HAuCl}_{4}$ ratio higher than 2 but its formation is retarded, probably by slow nucleation and crystal growth of a metastable $\mathrm{Au}_{2} \mathrm{~S}$ phase [55-58]. The reaction was concluded to proceed via non-classical pathway involving a series of pre-nucleation intermediates $(10-40 \mathrm{~nm}$ "clusters" and submicrometer droplets made up of "dense liquid" due to spinodal decomposition of supersaturated solutions), whose existence was confirmed using in situ atomic force microscopy, dynamic light scattering (DLS) and other techniques [57,58]. The question arises as to whether similar mechanisms occur in the selenide solutions, considering the stronger Au-Se bonding and thermodynamic stability of AuSe.

Here, we studied the interaction of aqueous tetrachloroauric acid with hydrogen selenide and their mixtures with hydrogen sulfide with focus on the media with initial molar chalcogenide-to-gold ratio of 3, when the reaction may be expected to proceed via the formation of the liquid intermediates. We employed XPS, TEM, electron and X-ray diffraction and other techniques to shed light onto morphology, composition, and chemical bonding in gold-selenide and sulfoselenides deposited from the solutions. The results of the research are important for understanding the fundamentals of nucleation, transportation, and deposition of noble metals in the nature, and in a future synthesis of gold chalcogenide nanomaterials.

\section{Materials and Methods}

The gold precursor was prepared by diluting the 0.1 mol aqueous stock solution of hydrogen tetrachloroaurate (98\% purity, the Krasnoyarsk Plant of Non-Ferrous Metals) with deionized water to 
obtain $0.3 \mathrm{mmol} / \mathrm{L} \mathrm{HAuCl}_{4}$ directly before the reaction. Hydrogen selenide and hydrogen sulfide were obtained via hydrolysis of $\mathrm{Al}_{2} \mathrm{Se}_{3}$ and $\mathrm{Al}_{2} \mathrm{~S}_{3}$ prepared by sintering $\mathrm{Al}$ powder with elemental selenium or sulfur in a quartz crucible. The gaseous hydrogen chalcogenides were absorbed by deionized water preliminary de-aerated by purging with Ar (grade 5.5) for $30 \mathrm{~min}$; the saturated solutions were sealed and kept at $5{ }^{\circ} \mathrm{C}$ for several days before application. The $\mathrm{H}_{2} \mathrm{Se}\left(\right.$ or $\left.\mathrm{H}_{2} \mathrm{~S}\right)$ solutions were diluted with de-aerated water to a desired concentration, which was verified by titration with elemental iodine and starch as indicator. In a typical procedure, a required volume $(0.075-0.75 \mathrm{~mL})$ of about $50 \mathrm{mmol} / \mathrm{L} \mathrm{H}_{2} \mathrm{Se}$ or $\mathrm{H}_{2} \mathrm{~S}$, or their mixture was quickly added to $0.3 \mathrm{mmol} / \mathrm{L} \mathrm{HAuCl}_{4}$ solution $(25 \mathrm{~mL})$ under vigorous agitation during $2 \mathrm{~min}$ and then left still at room temperature. In several experiments, $1 \mathrm{mmol} / \mathrm{L}$ cetyltrimethyl ammonium bromide (CTAB) was added afterwards in an attempt to stabilize the colloids formed. After predetermined time intervals, a portion of the solution was taken for examination.

UV-vis absorption spectra were collected in the range 200-1600 $\mathrm{nm}$ from the reaction mixtures loaded in a quartz cell with the light pass length of $2 \mathrm{~mm}$ using a Shimadzu UV 3600 spectrometer (Shimadzu, Kyoto, Japan). Hydrodynamic diameter (volume weighted mean size $Z_{\text {av }}$ ) and zeta-potentials of colloidal products were determined using a Zetasizer Nano ZS spectrometer (Malvern, Cambridge, UK) at scattering angle of $173^{\circ}$ in a folded polystyrene cell or polycarbonate cell with Pd electrodes.

TEM, energy dispersive X-ray analysis (EDS), and selected area electron diffraction (SAED) studies were performed using a JEOL JEM 2100 instrument (JEOL, Tokyo, Japan) operating at an accelerating voltage of $200 \mathrm{kV}$. To prepare a sample for examination, a droplet of the reaction solution was placed onto a $\mathrm{Cu}$ grid covered with a layer of amorphous carbon and allowed to dry in air at room temperature.

For XPS studies, a reaction solution droplet was dried at highly oriented pyrolytic graphite (HOPG). Generally, the spectra were taken both without washing and after water washing the residue; the results were essentially the same, and only those from washed specimens are presented here. The spectra were acquired using a SPECS spectrometer (SPECS, Berlin, Germany) equipped with a PHOIBOS 150 MCD-9 analyzer at electron take-off angle $90^{\circ}$ employing monochromatic Al $\mathrm{K} \alpha$ radiation $(1486.6 \mathrm{eV})$ of an $\mathrm{X}$-ray tube operated at $200 \mathrm{~W}$. The analyzer pass energy was $10 \mathrm{eV}$ for narrow scans, and $20 \mathrm{eV}$ for survey spectra. C 1s peak at $284.45 \mathrm{eV}$ from HOPG was used as a reference. The Au $4 f_{7 / 2,5 / 2}$, Se $3 d_{5 / 2,3 / 2}, S 2 p_{3 / 2,1 / 2}$ doublets were fitted, after subtraction of Shirley-type background, with coupled peaks with Gaussian-Lorentzian peak profiles, the spin-orbit splitting of $3.67 \mathrm{eV}, 0.88$ $\mathrm{eV}$, and $1.19 \mathrm{eV}$, and the branching ratios of $0.75,0.667$, and 0.5 , respectively, using CasaXPS software (version 2.3.16, Casa Software, Teignmouth, UK).

$\mathrm{X}$-ray diffraction was measured from residues precipitated from the solutions, rinsed with water, and deposited on Si support employing XPERT-PRO diffractometer (PANalytical, Almelo, The Netherlands) using $\mathrm{Cu} \mathrm{K} \alpha$ radiation $(30 \mathrm{~mA}, 40 \mathrm{kV}$ ). The Raman spectra in the backscattering geometry were recorded on a Horiba Jobin-Yvon T64000 spectrometer (Horiba, Kyoto, Japan) equipped with a liquid nitrogen cooled charge-coupled device detection system in subtractive dispersion mode. $\mathrm{Ar}^{+}$ion laser Spectra-Physics Stabilite 2017 with $\lambda=514.5 \mathrm{~nm}$ and power of $1 \mathrm{~mW}$ on a sample was used as an excitation light source.

\section{Results}

\subsection{UV-Vis Absorption Spectroscopy}

Figure 1 shows UV-vis spectra of the solutions with various initial molar ratios of $\mathrm{H}_{2} \mathrm{Se}$ to $\mathrm{HAuCl}_{4}$, and also $\mathrm{H}_{2} \mathrm{~S}$ to $\mathrm{HAuCl}_{4}$ after $1 \mathrm{~h}$ reaction. As the quantity of $\mathrm{H}_{2}$ Se increased, absorption peaks of tetrachloroaurate at $228 \mathrm{~nm}$ and $315 \mathrm{~nm}$ disappeared and the surface plasmon resonance of metallic gold nanoparticles arose near $530 \mathrm{~nm}$, but, in contrast to the reduction of $\mathrm{HAuCl}_{4}$ with sodium sulfide solution [50-57], no LSPR was observed in the near-IR spectral region. The LSPR vanished as the $\mathrm{H}_{2} \mathrm{Se} / \mathrm{HAuCl}_{4}$ ratio approached 2, and the spectra only slightly varied at the ratios of 3 and higher. 
The effect of the relative concentration of $\mathrm{H}_{2} \mathrm{~S}$ was similar but the absorption was notably lower than for the selenide systems in all the wavelength range. Previously, we found that the absorption $(\alpha)$ of the solutions with high $\mathrm{Na}_{2} \mathrm{~S} / \mathrm{HAuCl}_{4}$ ratios plotted as $(\alpha \mathrm{hv})^{1 / 2}$ vs. photon energy (hv) was linear, such as that of amorphous semiconductors with an indirect band gap. The gap width $\left(\mathrm{E}_{\mathrm{g}}\right) \mathrm{of} 1.43 \mathrm{eV}$ determined from the UV-vis spectra [55-57] was attributed to $\mathrm{Au}_{2} \mathrm{~S}$-like species in "dense droplets" of supersaturated solutions, although the exact nature of this soft material is obscure. The effect of the ratios of $\mathrm{H}_{2} \mathrm{Se}$ and $\mathrm{H}_{2} \mathrm{~S}$ to $\mathrm{HAuCl}_{4}$ on the band gap is shown Figure 1c. The $\mathrm{E}_{\mathrm{g}}$ values increased up to $1.07 \mathrm{eV}$ and $2.0 \mathrm{eV}$ for $\mathrm{H}_{2} \mathrm{Se}$ and $\mathrm{H}_{2} \mathrm{~S}$, respectively, as the initial chalcogen/gold ratios changed from 2 to 3.5 , and then slowly decreased. The gap widths are in reasonable agreement with the values of $0.6 \mathrm{eV}$ and $0.7 \mathrm{eV}$ reported for bulk $\alpha$ - and $\beta$-AuSe, respectively [37], and those ranged from $1.3 \mathrm{eV}$ to $2.6 \mathrm{eV}$ for $\mathrm{Au}_{2} \mathrm{~S}$ [50-57]. Therefore, this parameter has a physical meaning related to $\mathrm{Au}-\mathrm{Se}$ and $\mathrm{Au}-\mathrm{S}$ bonding and can be used at least for monitoring the reaction.
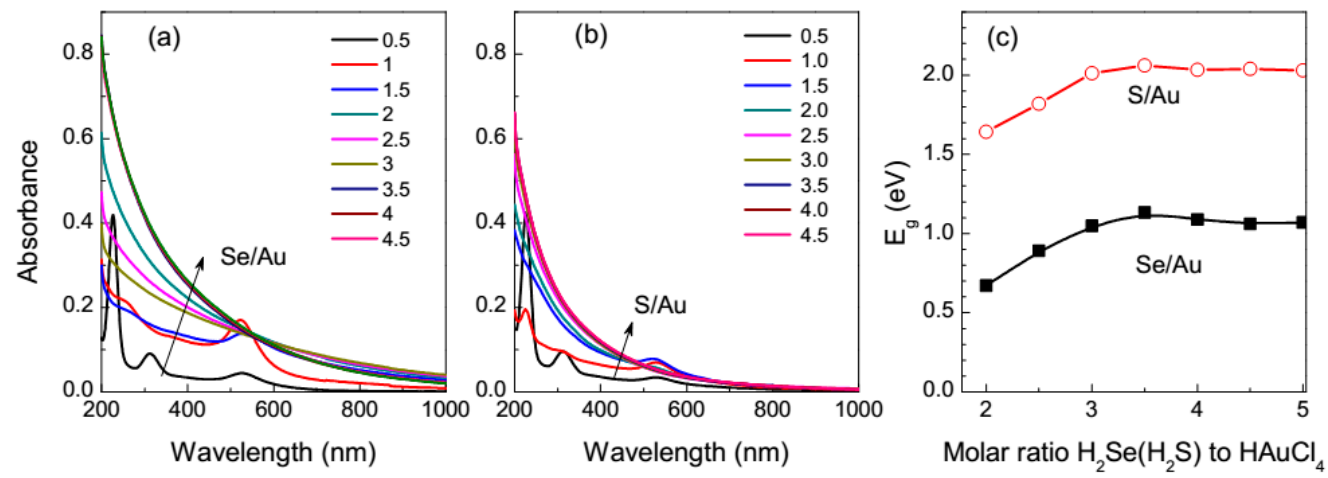

Figure 1. UV-vis absorption spectra of the reaction solutions measured after $1 \mathrm{~h}$ reaction at various molar ratios (a) $\mathrm{H}_{2} \mathrm{Se}$ to $\mathrm{HAuCl}_{4}$ and (b) $\mathrm{H}_{2} \mathrm{~S}$ to $\mathrm{HAuCl}_{4}$ shown in the legend. (c)The indirect band gaps determined from $(\alpha h v)^{1 / 2}$ vs photon energy $(h v)$ plots for the UV-vis spectra as a function of the ratio of $\mathrm{H}_{2} \mathrm{Se}\left(\mathrm{H}_{2} \mathrm{~S}\right)$ to $\mathrm{HAuCl}_{4}$.

The spectra of the reaction mixtures with the molar ratio $\left(\mathrm{H}_{2} \mathrm{Se}+\mathrm{H}_{2} \mathrm{~S}\right) / \mathrm{HAuCl}_{4}=3$ presented in Figure 2 demonstrate that the optical absorption increased and the $\mathrm{E}_{\mathrm{g}}$ magnitude gradually reduced upon increasing the proportion of $\mathrm{H}_{2} \mathrm{Se}$, and the $\mathrm{E}_{\mathrm{g}}$ vs. $\mathrm{H}_{2} \mathrm{Se} /\left(\mathrm{H}_{2} \mathrm{Se}+\mathrm{H}_{2} \mathrm{~S}\right)$ is asymmetric due to stronger Au-Se bonding in comparison with $\mathrm{Au}-\mathrm{S}$ bonding.
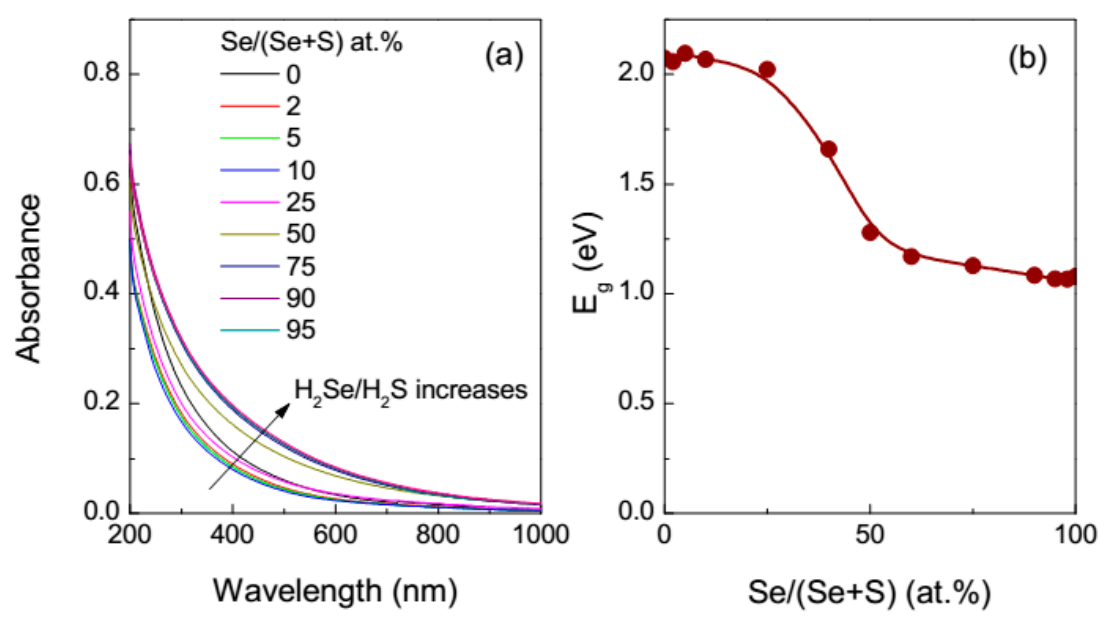

Figure 2. (a) UV-vis absorption spectra of the mixed $\mathrm{H}_{2} \mathrm{Se} / \mathrm{H}_{2} \mathrm{~S}$ reaction media with the total molar ratio hydrogen chalcogenide to $\mathrm{HAuCl}_{4}$ of 3 and (b) the indirect band gaps determined from the UV-vis spectra as a function of the ratio $\mathrm{H}_{2} \mathrm{Se} / \mathrm{H}_{2} \mathrm{~S}$ after $1 \mathrm{~h}$ reaction. 
The media formed are stable at least for several hours, depending on the composition, with the absorption increasing and the $E_{g}$ parameter slowly decreasing with the reaction time (Figure 3).
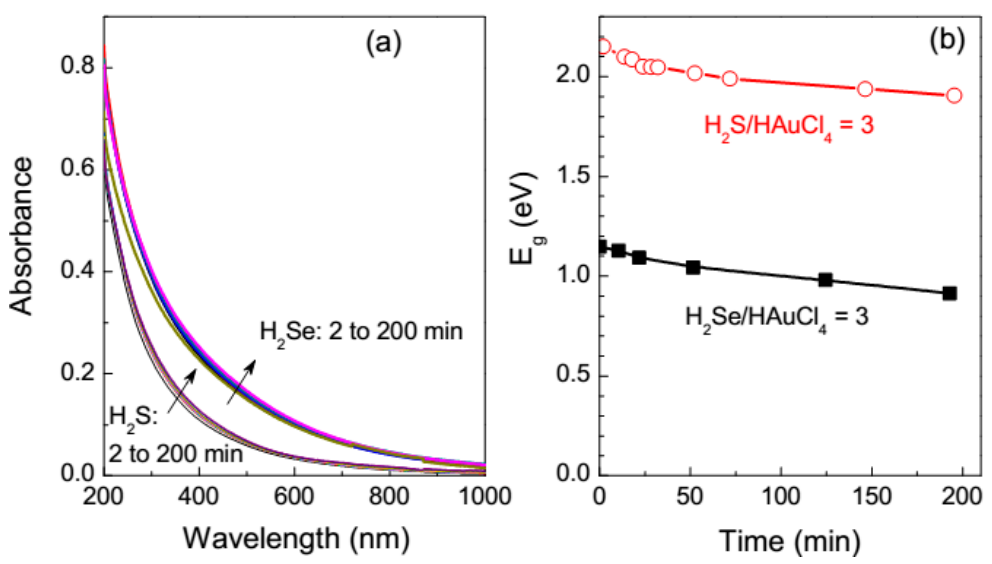

Figure 3. (a) UV-vis absorption spectra of the reaction solutions with the molar ratios $\mathrm{H}_{2} \mathrm{Se} / \mathrm{HAuCl}_{4}=3$ and $\mathrm{H}_{2} \mathrm{~S} / \mathrm{HAuCl}_{4}=3$, and (b) the in direct band gaps calculated from the UV-vis spectra as a function of reaction time.

\subsection{Dynamic Light Scattering and Zeta-Potential Measurement}

DLS and zeta-potential measurements (Figure 4) reveal nanoscale entities with the average hydrodynamic diameter $\left(Z_{\mathrm{av}}\right)$ of 20-40 $\mathrm{nm}$ and negative surface charges after $1 \mathrm{~h}$ reaction at the ratios of $\mathrm{H}_{2} \mathrm{Se}$ (or $\mathrm{H}_{2} \mathrm{~S}$ ) to $\mathrm{HAuCl}_{4}$ below 2. The above UV-vis spectra and previous results [50-57] suggest that these values correspond to gold nanoparticles, although the reaction seems to be not completed and $\mathrm{Au}^{+}$-chalcogenide intermediates are also present. Both $Z_{\mathrm{av}}$ and zeta potential (ranged from $-50 \mathrm{mV}$ to $-40 \mathrm{mV}$ ) moderately varied with the $\mathrm{H}_{2} \mathrm{Se} / \mathrm{HAuCl}_{4}$ ratio. On the contrary, the hydrodynamic diameter gradually decreased with increasing concentration of $\mathrm{H}_{2} \mathrm{~S}$ and sharply enhanced from $20 \mathrm{~nm}$ to about $300 \mathrm{~nm}$ as the $\mathrm{H}_{2} \mathrm{~S} / \mathrm{HAuCl}_{4}$ ratio reached 3; correspondingly, zeta-potential magnitude altered from $-40 \mathrm{mV}$ to $-10 \mathrm{mV}$ and then to $-55 \mathrm{mV}$. Such behavior can be explained in terms of a lower stability of $\mathrm{Au}-\mathrm{S}$ intermediates and a higher rate of the reaction yielding $\mathrm{Au}^{0}$ with sulfide than selenide (see Discussion below). In both the selenide and sulfide media with the chalcogenide-to-gold proportion of 3 and higher, the values of zeta potential are close to $-50 \mathrm{mV}$, which may be considered as a signature of the "dense" liquid intermediates.
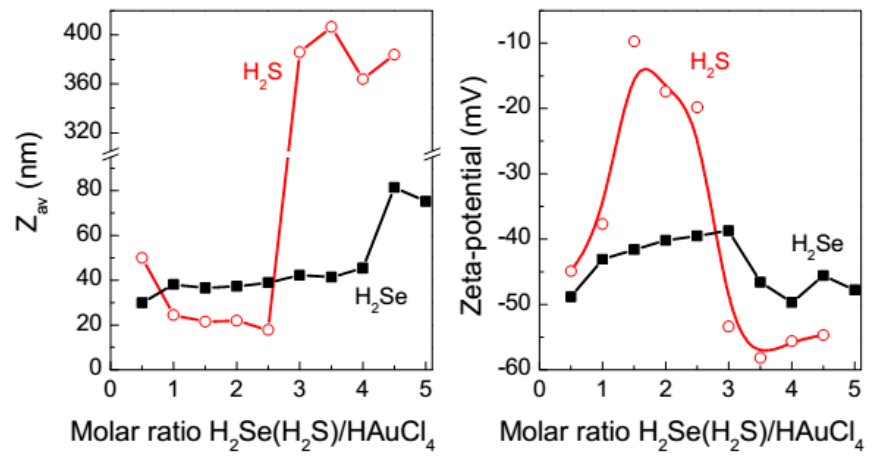

Figure 4. Hydrodynamic diameters $Z_{\mathrm{av}}$ and zeta-potentials of the colloidal species at various ratios $\mathrm{H}_{2} \mathrm{Se}$ and $\mathrm{H}_{2} \mathrm{~S}$ to $\mathrm{HAuCl}_{4}$ determined in $1 \mathrm{~h}$ after mixing the reactants.

Figure 5 shows evolution of $Z_{\mathrm{av}}$ with time after addition of $\mathrm{H}_{2}$ Se or $\mathrm{H}_{2} \mathrm{~S}$ to aqueous $\mathrm{HAuCl}_{4}$ at the molar ratio of 3 to 1 . The hydrodynamic diameter rather slowly increased in the gold-selenide medium during 6-8 h, and rapidly afterwards (the big species observed in the first minutes and then 
dissolved likely originate from local supersaturation immediately after mixing the reactants). Similar behavior was previously found for the interaction of tetrachloroaurate with sodium sulfide solutions and interpreted in terms of slow coalescence of dense liquid nanoscale droplets ("clusters") into submicrometer droplets $[57,58]$. However, in the reaction involving $\mathrm{H}_{2} \mathrm{~S}$, the sulfide-containing species rapidly grew up to approximately $500 \mathrm{~nm}$ in less than $2 \mathrm{~h}$. Nucleation (within the submicrometer droplets) and precipitation of both gold chalcogenides is not instant but gradual and poorly reproducible, unless very high concentrations of chalcogenide ions or an injection of electrolyte were applied; this is illustrated in Figure 4 for the case of $\mathrm{H}_{2} \mathrm{~S}$. Some insight into the nucleation and coagulation in $\mathrm{Na}_{2} \mathrm{~S}+\mathrm{HAuCl}_{4}$ solutions was reported elsewhere [58] but the phenomena require further investigation.

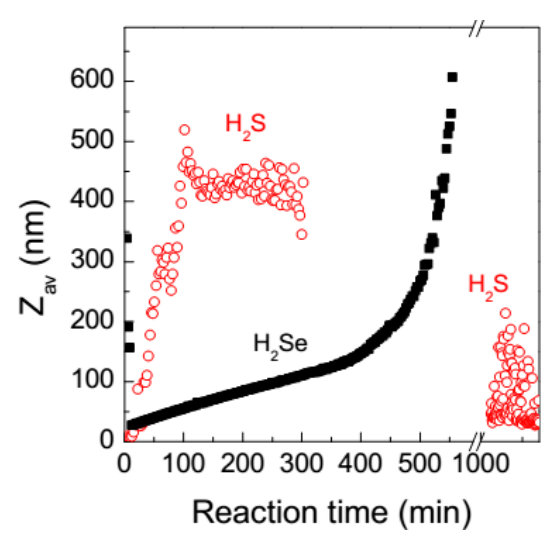

Figure 5. Evolution of average hydrodynamic diameter $\left(\mathrm{Z}_{\mathrm{av}}\right)$ with time after mixing aqueous solutions of $\mathrm{H}_{2} \mathrm{Se}$ or $\mathrm{H}_{2} \mathrm{~S}$ with $\mathrm{HAuCl}_{4}$ at the molar ratio 3 to 1 .

The effect of substitution of $\mathrm{H}_{2} \mathrm{~S}$ for $\mathrm{H}_{2}$ Se on the properties of colloidal products is difficult to elucidate because of very different reaction rates. In the initial stages, when smaller dense liquid species are believed to arise and submicrometer droplets are absent yet [55-58], a steady increase in $Z_{\mathrm{av}}$ from $20 \mathrm{~nm}$ to $40 \mathrm{~nm}$ and zeta-potential magnitude from about $-35 \mathrm{mV}$ to $-50 \mathrm{mV}$ as the relative concentration of $\mathrm{H}_{2}$ Se increased (Figure S1, Supplementary data).

\subsection{TEM}

The reaction products were further examined using ex situ TEM, electron diffraction, XPS, XRD, Raman scattering. These techniques are commonly employed, in particular, in wet chemical synthesis to characterize nanoscale materials, which, however, may be modified by immobilization and drying.

Representative TEM images of the species formed via the interaction of tetrachloroauric acid with hydrogen selenide, hydrogen sulfide and their 1-to-1 mixture at the initial molar ratio hydrogen chalcogenide/ $\mathrm{HAuCl}_{4}$ of 3 are given in Figure 6 . The products of the reaction with hydrogen selenide are about $40 \mathrm{~nm}$ aggregates composed of irregular 5-10 nm particles of two sorts, dense and low-contrast, along with lesser contrast loose material. High-resolution TEM (HR-TEM) (Figure 6b) and the relevant Fourier transforms from the less dense species revealed interplanar distances of 3.2-3.3 $\AA$. At the same time, electron diffraction (Figure 6c) showed diffuse circles from elemental gold ( $\mathrm{d}=2.33 \AA, 2.02 \AA, 1.43 \AA$, etc., PDF 00-004-0784), which is present as the larger dense NPs. The circles corresponding to $\mathrm{d}=3.29 \AA, 1.72 \AA, 1.31 \AA$ likely originate from a gold-selenide compound; meanwhile, the strongest reflections from either $\alpha$-AuSe $\left(\mathrm{d}_{310}=2.70 \AA, \mathrm{d}_{003}=2.74 \AA, \mathrm{d}_{313}=1.79 \AA\right.$, PDF 00-020-0457), or $\beta$-AuSe $\left(\mathrm{d}_{111}=2.79 \AA, \mathrm{d}_{002}=4.02 \AA\right.$, etc., PDF 00-020-0458) are absent.

In the case of the mixture of $\mathrm{H}_{2} \mathrm{Se}$ and $\mathrm{H}_{2} \mathrm{~S}$, TEM shows (Figure 6d,e) preferentially separated $\mathrm{Au}$ NPs of 5-6 nm in size with the interplanar distances of $\sim 2.2-2.3 \AA$ (observed in HR-TEM), and low-contrast species with the distances of 3.2-3.3 $\AA$ and 3.0-3.1 $\AA$. Electron diffraction revealed, in addition to gold, weak reflections at $3.48 \AA, 3.10 \AA, 1.72 \AA$. The products of the reaction with $\mathrm{H}_{2} \mathrm{~S}$ 
(Figure 6g-i) represented a network-like structure formed by low-contrast wires and $\sim 3 \mathrm{~nm}$ Au NPs, the quantity of which visibly grew under the electron beam; very similar images were obtained with $\mathrm{Na}_{2} \mathrm{~S}$ solution [55]. In addition to metallic gold, electron diffraction shows very weak diffuse reflections at $2.83 \AA$ and possibly some others attributable to gold sulfide (i.e., $\mathrm{d}_{111}=2.89 \AA$, PDF 04-007-4652).
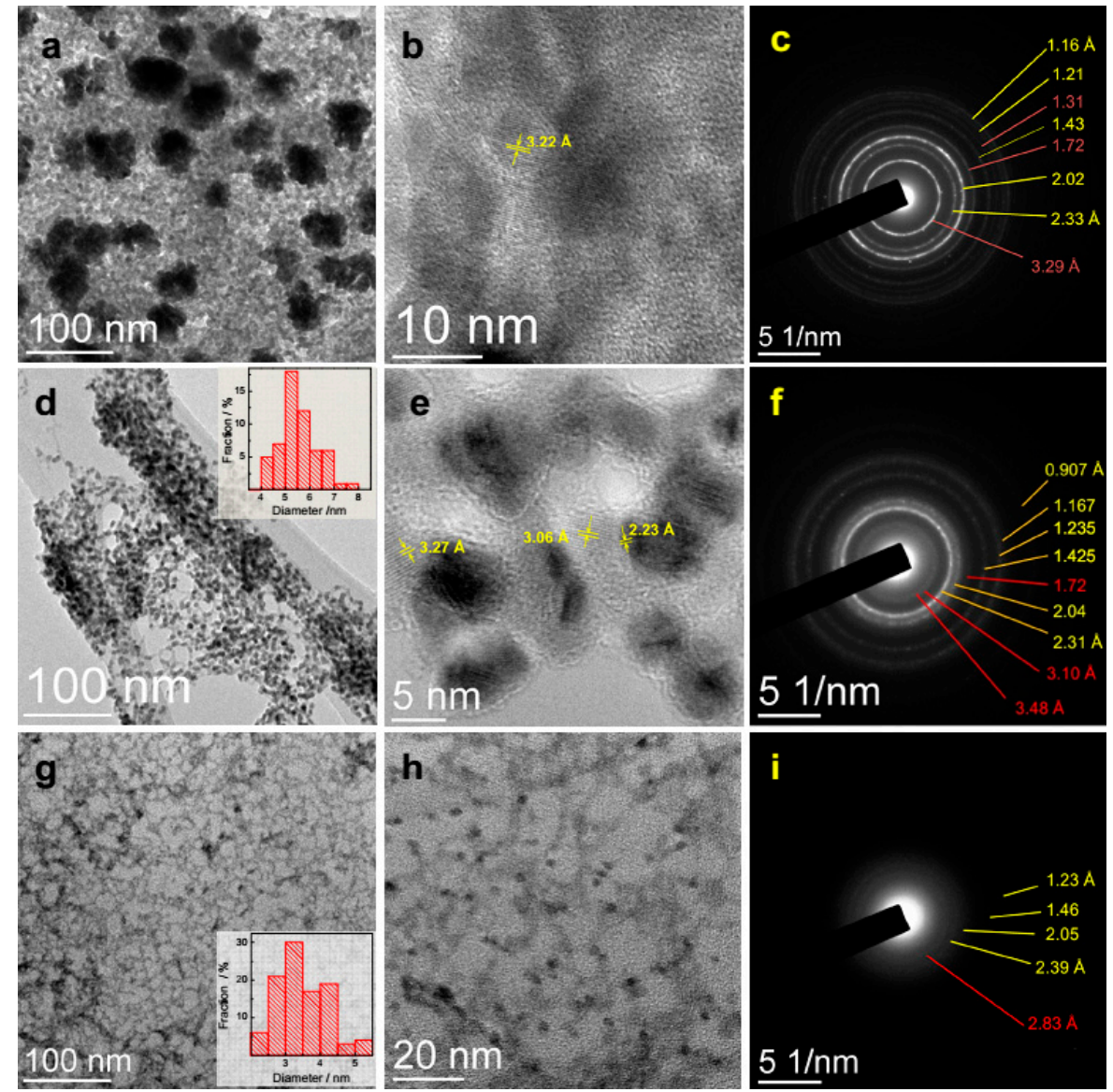

Figure 6. TEM images and selected area electron diffraction patterns of the air-dried solutions of (a-c) $0.3 \mathrm{mmol} / \mathrm{L} \mathrm{HAuCl}_{4}+0.9 \mathrm{mmol} / \mathrm{L} \mathrm{H}_{2} \mathrm{Se}$, (d-f) $0.3 \mathrm{mmol} / \mathrm{L} \mathrm{HAuCl}_{4}+0.45 \mathrm{mmol} / \mathrm{L} \mathrm{H}_{2} \mathrm{Se}+$ $0.45 \mathrm{mmol} / \mathrm{L} \mathrm{H}_{2} \mathrm{~S} ;(\mathbf{g}-\mathbf{i}) 0.3 \mathrm{mmol} / \mathrm{L} \mathrm{HAuCl}_{4}+0.9 \mathrm{mmol} / \mathrm{L} \mathrm{H}_{2} \mathrm{~S}$ after about $1 \mathrm{~h}$ reaction. The data illustrate the formation of gold nanoparticles via post-synthetic decomposition of disordered gold chalcogenides (less contrast material), see the text for detail.

EDS analysis (Figure S2, Supplementary data) of the Au-Se products found average atomic Se/Au ratios an order of 2, with essentially inhomogeneous spatial distribution of the elements that varied from less than 1 at the dense nanoparticles attributable to $\mathrm{Au}^{0}$ to $\sim 3$ for the low-contrast material; a small amount of $\mathrm{Cl}$ (atomic proportion $\mathrm{Cl} / \mathrm{Au}$ of $\sim 0.1$ ) was also detected. For the mixture (1:1) of $\mathrm{H}_{2} \mathrm{Se}$ and $\mathrm{H}_{2} \mathrm{~S}$, the average composition of the products approached $(\mathrm{Se}+\mathrm{S}) / \mathrm{Au} \sim 1$, and also was spatially inhomogeneous. The products formed with $\mathrm{H}_{2} \mathrm{~S}$ had the atomic $\mathrm{S} / \mathrm{Au}$ proportion less than 1 that decreased with time due to rapid decay and volatization of $S$.

The results suggest that some share of Se and especially $S$ might evaporate in vacuum under electron beam, but gold-selenide species observed with TEM/SAED/EDS still contain excessive selenium relative to AuSe. The interplanar distance of $\sim 3.2 \AA$ is a signature of the Au-Se-based structures, and this parameter decreases to $3.0 \AA$ for $\mathrm{Au}-(\mathrm{Se}, \mathrm{S})$ and $2.9 \AA$ for $\mathrm{Au}-\mathrm{S}$; these values may be close to $\mathrm{Au}-\mathrm{Au}$ distances [11,12,30-32] but different from $d$ values in the gold chalcogenides. The data describe immobilized intermediates somewhat distorted due to drying and evaporation of chalcogens, density of which decreased with substitution of Se for $S$, as it is seen in TEM images. Furthermore, 
decomposition of the gold chalcogenide species yielded gold nanoparticles, the dimensions of which decreased from $\mathrm{Au}-\mathrm{Se}$ to Au-S systems, probably because of more stable Au-Se bonding, slower nucleation, and smaller number of Au nuclei, and then larger Au NPs, or denser liquid species, or both factors, which can be in fact interrelated.

\subsection{X-ray Diffraction Analysis and Raman Scattering}

XRD patterns (Figure 7a) show a very wide maximum and a shoulder corresponding to interplanar distances of roughly $2.8 \AA$ and $1.8 \AA$, respectively, which are near to $\mathrm{d}_{310}$ and $\mathrm{d}_{313}$ planes in $\alpha$-AuSe (PDF 00-020-0457), or to $\mathrm{d}_{111}$ (and $\mathrm{d}_{200}$ ) plane in $\mathrm{Au}_{2} \mathrm{~S}$. At the same time, reflections of elemental gold are absent. This means that highly are bulk products of the reactions with high contents of hydrogen chalcogens, whereas $\mathrm{Au}^{0}$ NPs disordered gold chalcogenides observed in TEM, SAED, and XPS (below) is surface species formed ex situ.
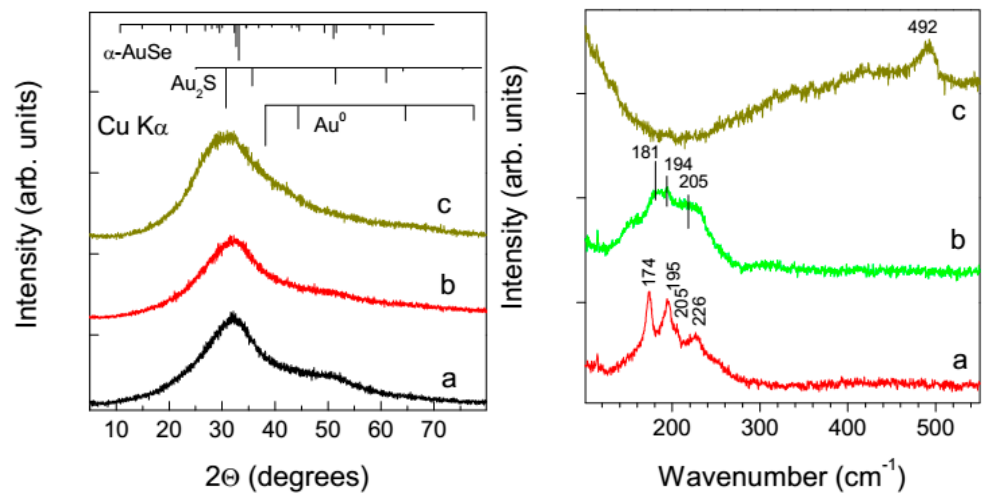

Figure 7. X-ray diffraction patterns (left panel; the reflections of $\mathrm{Au}^{0}, \mathrm{Au}_{2} \mathrm{~S}$, and $\alpha$-AuSe are shown for comparison) and Raman scattering (right panel) of the products deposited from aqueous solutions of (a) $0.3 \mathrm{mmol} / \mathrm{L} \mathrm{HAuCl}_{4}+0.9 \mathrm{mmol} / \mathrm{L} \mathrm{H}_{2} \mathrm{Se}$, (b) $0.3 \mathrm{mmol} / \mathrm{L} \mathrm{HAuCl}_{4}+0.45 \mathrm{mmol} / \mathrm{L} \mathrm{H}_{2} \mathrm{Se}+0.45 \mathrm{mmol} / \mathrm{L}$ $\mathrm{H}_{2} \mathrm{~S}$; (c) $0.3 \mathrm{mmol} / \mathrm{L} \mathrm{HAuCl}_{4}+0.9 \mathrm{mmol} / \mathrm{L} \mathrm{H}_{2} \mathrm{~S}$ after $1 \mathrm{~h}$ reaction and dried in air.

Raman spectra of the residue obtained from the $\mathrm{HAuCl}_{4}+3 \mathrm{H}_{2} \mathrm{Se}$ medium detected a set of Au-Se stretches $\left(174 \mathrm{~cm}^{-1}, 195 \mathrm{~cm}^{-1}, 205 \mathrm{~cm}^{-1}, 226 \mathrm{~cm}^{-1}\right)$ characteristic of AuSe crystals overlapped with a broad band attributable to a disordered material. The lines widened and slightly shifted if the mixture of $\mathrm{H}_{2} \mathrm{Se}$ and $\mathrm{H}_{2} \mathrm{~S}$ was used, suggesting further disordering of gold chalcogenide phase. The Se-Se stretching that is expected to be around 290-330 $\mathrm{cm}^{-1}$ [59] was not detected. The spectrum from the products of the reaction $\mathrm{HAuCl}_{4}+3 \mathrm{H}_{2} \mathrm{~S}$ showed a broad band near $490 \mathrm{~nm}$ that is due to $\mathrm{S}-\mathrm{S}$ stretching frequencies, probably from $S$ adsorbed at Au NPs, while Au-S stretches near $270 \mathrm{~cm}^{-1}$ [55,59] are absent. This agrees with previous findings of a range of $\mathrm{Au}-\mathrm{S}$ and $\mathrm{S}-\mathrm{S}$ vibrations at lower concentrations of sulfide when metallic nanogold formed, and disappearance of the bands at the molar ratio 1-to-3 [55]. As the Raman spectra are in fact surface-enhanced due to an intimate contact of chalcogenides with gold nanoparticles, no enhancement of Raman spectra of $\mathrm{Au}_{2} \mathrm{~S}$ was observed with $\mathrm{H}_{2} \mathrm{~S}$ because the contact between $\mathrm{Au}_{2} \mathrm{~S}$ and $\mathrm{Au}$ NPs was insignificant, in contrast to the systems containing $\mathrm{H}_{2} \mathrm{Se}$ (see TEM images in Figure 6).

\subsection{X-ray Photoelectron Spectroscopy}

X-ray photoelectron spectra (Figure 8, see also Table S1, Supplementary data) characterize the net composition and chemical state of atoms in surface layers of roughly $2 \mathrm{~nm}$ thick, which, though, may be modified in the ultra-high vacuum conditions and under X-ray irradiation. The binding energy (BE) of the main peak $\mathrm{Au} 4 \mathrm{f}_{7 / 2}(84.14 \pm 0.05 \mathrm{eV})$ is slightly higher than that of bulk metal $(84.0 \mathrm{eV})$; this may be due to either the final state effect that is characteristic of nanoparticles less than about $5 \mathrm{~nm}$, or the chemical shift caused by the transfer of electrons from Au to chalcogen atoms [60,61]. A second, less intense peak at $85.4 \pm 0.1 \mathrm{eV}$ decreased several times and slightly shifted to a higher BE 
upon substitution of $\mathrm{H}_{2} \mathrm{Se}$ for $\mathrm{H}_{2} \mathrm{~S}$ in the reaction media. Also, there is a minor signal at $86.4 \mathrm{eV}$ from $\mathrm{Au}^{3+}-\mathrm{Cl}$ species.
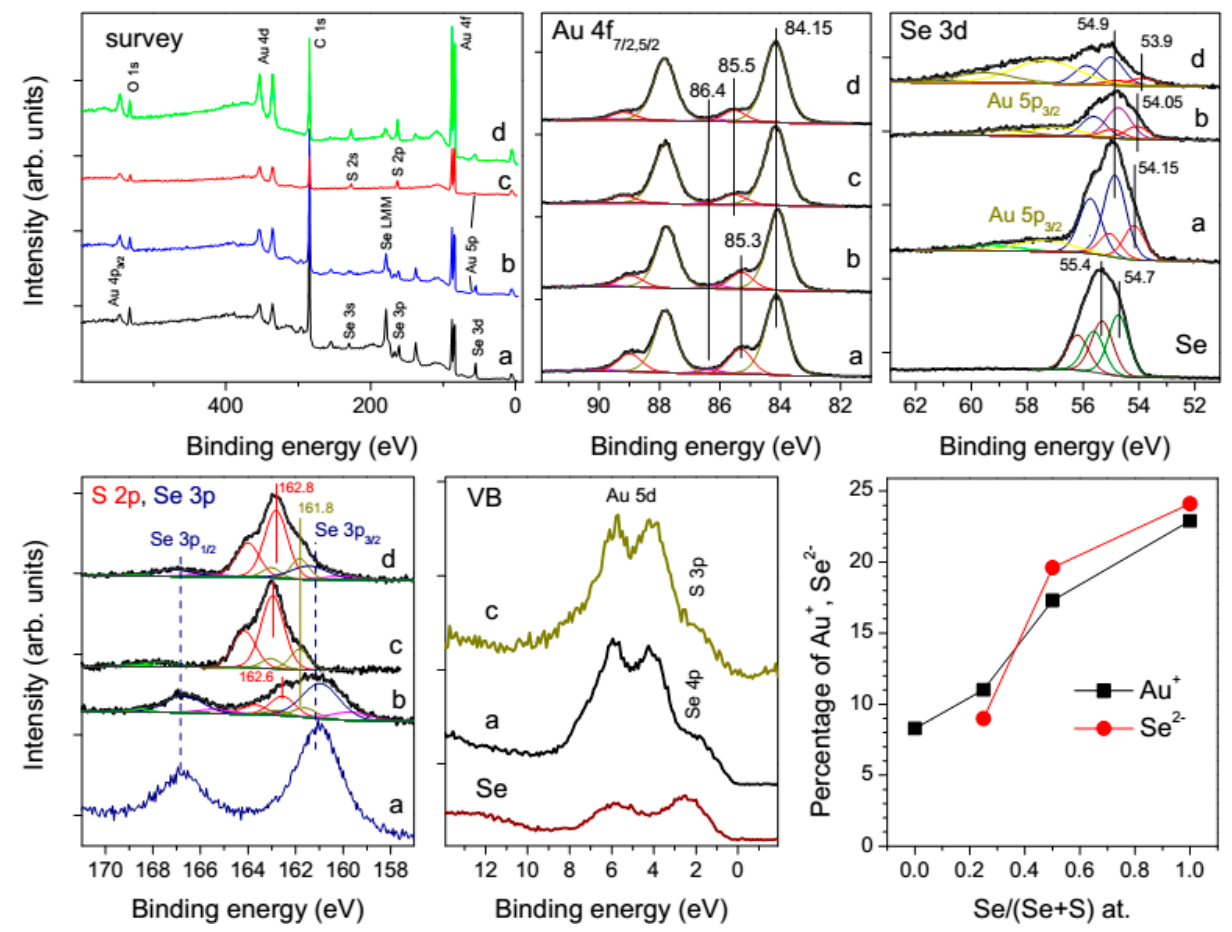

Figure 8. X-ray photoelectron spectra from sols produced via the reaction of aqueous $\mathrm{HAuCl}_{4}$ $(0.3 \mathrm{mmol} / \mathrm{L})$ with hydrogen selenide and sulfide, dried at HOPG and washed with water (a) $3 \mathrm{H}_{2} \mathrm{Se}$, (b) $1.5 \mathrm{H}_{2} \mathrm{Se}+1.5 \mathrm{H}_{2} \mathrm{~S}$, (c) $3 \mathrm{H}_{2} \mathrm{~S}$, (d) $3 \mathrm{H}_{2} \mathrm{~S}$ and then $\mathrm{H}_{2} \mathrm{Se}$, and from elemental Se powder. The lower right panel shows percentage of $\mathrm{Au}^{+}(\mathrm{BEs}$ about $85.4 \mathrm{eV})$ and selenide $(54.2 \mathrm{eV})$ for these products.

The Se 3d spectra, which are partially overlapped with Au 5 $\mathrm{p}_{3 / 2}$ bands, can be fitted using two doublets at $54.9 \mathrm{eV}$ (more intense) and $54.1 \pm 0.1 \mathrm{eV}$, with the relative intensity of the weaker low-energy component decreased and its position slightly shifted to lower BEs with increasing share of $\mathrm{H}_{2} \mathrm{~S}$ in the reaction media. For comparison, the Se $3 \mathrm{~d}$ spectrum of a commercial powder of elemental Se was fitted using two doublets with the Se $3 \mathrm{~d}_{5 / 2}$ peaks at $54.7 \mathrm{eV}$ and $55.3 \mathrm{eV}$ and $55.3 \mathrm{eV}$, which may be assigned to mono- and polymeric $\mathrm{Se}^{0}$ species [59].

The BE of the main maximum S 2 $\mathrm{p}_{3 / 2}$ at about $163 \mathrm{eV}$ (note that $\mathrm{S} 2 \mathrm{p}$ spectra are overlain by Se $3 \mathrm{p}$ bands in case of $\mathrm{H}_{2} \mathrm{Se} / \mathrm{H}_{2} \mathrm{~S}$ mixture) can be ascribed to polysulfide anions or polymeric $\mathrm{S}$ adsorbed at gold. A smaller component at $161.8 \mathrm{eV}$ originates from monosulfide ions in gold chalcogenide phases or/and chemisorbed atomic S [56]; the proportion of monosulfide is higher in a blend with $\mathrm{H}_{2} \mathrm{Se}$. Insignificant contributions of oxysulfur compounds are observed around $168 \mathrm{eV}$.

The atomic chalcogen/ $\mathrm{Au}$ ratio is close to 1 for the reaction $\mathrm{H}_{2} \mathrm{Se}+\mathrm{HAuCl}_{4}$ and somewhat increases with growing content of $\mathrm{H}_{2} \mathrm{~S}$, while the intensities of the smaller $\mathrm{Au} 4 \mathrm{f}$ component at $85.5 \mathrm{eV}$ and the Se $3 \mathrm{~d}$ band at $54.2 \mathrm{eV}$ enhance with increasing the relative concentration of $\mathrm{H}_{2} \mathrm{Se}$ and retain their atomic ratio of about 1 under various conditions (Figure 8). The findings, which seemingly disagree with an excess of chalcogens found with EDS and also with a higher volatility of sulfur as compared with selenium, can be rationalized in terms of surface decomposition of gold chalcogenides, and different lateral resolution and probing depths of the techniques. The assignment of the Au 4f components is not straightforward, particularly, since AuSe contains two sorts of Au atoms, the oxidation state of which is a matter of dispute [35-45]. The $\mathrm{Au} 4 \mathrm{f}_{7 / 2}$ peaks at 84.0-84.4 eV reported for gold-gold selenide [39-41], gold-CdSe [44,45]), adlayers of Se or alkyl selenides at Au [45-49,59], etc., originate from $\mathrm{Au}^{0}$ surfaces but not AuSe phases. In nanostructured AuSe with admixture of $\mathrm{Au}$ [42], the values of $83.7 \mathrm{eV}$ and $84.9 \mathrm{eV}$ have been found, along with Se $3 \mathrm{~d}_{5 / 2}$ line at $54.5 \mathrm{eV}$, 
and ascribed to $\mathrm{Au}^{0}$ and $\mathrm{Au}^{+}$, respectively; nevertheless, the authors assert the mixed valence state of gold $\left(\mathrm{Au}^{+} \mathrm{Au}^{3+} \mathrm{Se}_{2}\right)$. The BEs from $84.2 \mathrm{eV}$ to $84.7 \mathrm{eV}$ attributed to $\mathrm{Au}^{+}$in a series $\mathrm{Ag}-\mathrm{Au}$ sulfides, selenides and sulfoselenides increase with decreasing content of Ag and the transfer of electron density from $\mathrm{Ag}$ to $\mathrm{Au}$ atoms [60,61]. These values should be higher in AuSe and $\mathrm{AuSe}_{1-\mathrm{x}} \mathrm{S}_{\mathrm{x}}$ compounds where silver is absent, so we assign the component at $85.4 \mathrm{eV}$ and the Se $3 \mathrm{~d}$ doublet at $54.2 \mathrm{eV}$ to $\mathrm{Au}^{+}$ and $\mathrm{Se}^{2-}$ centers, respectively. The valence band spectra (Figure 8) are similar for the products of the reactions of $\mathrm{HAuCl}_{4}$ with $\mathrm{H}_{2} \mathrm{Se}$ and $\mathrm{H}_{2} \mathrm{~S}$, with low if any density of $\mathrm{Au} 5 \mathrm{~d}$ states near the Fermi level, suggesting that the $\mathrm{Au} 5 \mathrm{~d}$ band is completely occupied, and $\mathrm{Au}^{3+}$ centers do not occur in the AuSe phases.

The largest contribution to the VB and Au 4f spectra comes from metallic Au NPs (BE of 84.1 eV) capped with elemental selenium (BE of $54.8 \mathrm{eV}$ ) or a mixture of Se and $\mathrm{S}$ and formed via decomposition of $\mathrm{AuSe}(\mathrm{S})$ phases and partial evaporation of chalcogens. The yield of $\mathrm{Au}^{0}$ is lower in the $\mathrm{Au}-\mathrm{Se}$ system and increases with addition of $\mathrm{H}_{2} \mathrm{~S}$ because of stronger $\mathrm{Au}$ bonding to Se than $\mathrm{S}$. This is mainly surface phenomena as UV-vis spectra show no plasmon peaks from metallic gold NPs in the solutions with the ratio $\mathrm{H}_{2} \mathrm{Se}\left(\mathrm{H}_{2} \mathrm{~S}\right)$ to $\mathrm{HAuCl}_{4}$ of 3 or larger, and XRD revealed no gold reflections for bulk precipitates. Capping ligands, in particular, CTAB (see Table S1, Supplementary data) to some extent inhibited decomposition of AuSe, and their effect is worthy of further investigation.

\section{Discussion}

The reaction $\mathrm{H}_{2} \mathrm{Se}\left(\mathrm{H}_{2} \mathrm{~S}\right)+\mathrm{HAuCl}_{4}$ proceeds similarly to the $\mathrm{Na}_{2} \mathrm{~S}+\mathrm{HAuCl}_{4}$ [50-58], and we assume an analogous mechanism involving pre-nucleation dense liquid intermediates at the molar ratios of hydrogen chalcogenide to $\mathrm{HAuCl}_{4}$ of 3 and higher. The Au-Se bonding is more favorable than the Au-S so one could expect a higher rate of nucleation of AuSe and shorter lifetime of liquid intermediates. Instead, we observed much slower growth of the nanoscale clusters, subsequent nucleation of gold chalcogenides in the interior of the droplets, and their coagulation in the reaction with $\mathrm{H}_{2} \mathrm{Se}$ than with $\mathrm{H}_{2} \mathrm{~S}$. This likely relates with a denser gold chalcogenide material as seen in TEM, larger concentrations of chalcogenide (Se), and a higher magnitude of the negative zeta-potentials of the nanoscale fluid clusters in the initial stages; these factors appeared to impede coalescence of the clusters into submicrometer droplets. At the same time, the stronger Au-Se bonding retards ex situ surface decomposition of AuSe yielding $\mathrm{Au}^{0} \mathrm{NPs}$, in comparison with gold-sulfide system. Noteworthy, the reaction is faster with $\mathrm{H}_{2} \mathrm{~S}$ than with $\mathrm{Na}_{2} \mathrm{~S}$ [55-58] probably due to lower $\mathrm{pH}$ and so concentration of $\mathrm{S}^{2-}$ anion. The substitution of selenium for sulfur also causes gradual increase of the band gap derived from UV-vis absorption spectra. Such parameters as interplanar distances in HR-TEM and electron diffraction, the binding energies of photoelectron Se and Au lines change steadily too, so it seems likely, but not certain, that $S$ can partially replace Se in the dense liquid intermediates; the effect was observed for any order of mixing the reactants.

The crystal structures of $\alpha$ - and $\beta$-AuSe are well understood [30-32], but their electronic structure, particularly, the oxidation state of gold is a matter of dispute. The X-ray photoelectron Au $4 \mathrm{f}$ and valence band spectra (Figure 8) imply only one form of $\mathrm{Au}^{+}$and $\mathrm{Se}^{2-}$ both in linear and plain-square coordination of Au with Se (see also [42]). These findings agree with the results of quantum chemical calculations [37] and X-ray absorption spectra [36], but contradict ${ }^{197} \mathrm{Au}$ Mössbauer spectra [35], in which two types of $\mathrm{Au}$ atoms have been found both in $\alpha$-AuSe and $\beta$-AuSe. The discrepancy is likely due to liquid helium temperature used in the Mössbauer experiment. The spectra of bulk crystalline materials [60,61], including those measured from gold selenides and sulfoselenides (will be published elsewhere), support the above interpretation. On the other hand, XPS, as well as TEM and other techniques evidenced the formation of elemental gold via decomposition of surface layers of disordered gold selenides in air and vacuum, so adjacent gold-selenide phase might be distorted.

The non-classical pathway of gradual nucleation within a dense droplet and crystal growth, arrested possibly due to a lack of solutes accumulated within other liquid species, is believed to prevent crystallization of gold chalcogenides and results in their compromised structure inclined 
to decompose to metallic gold. Such reactions can play a role in the deposition of gold colloids in several types of ores $[62,63]$, even although the hydrothermal processes proceed at higher temperatures and in a different time scale, resulting, in particular, in crystallization and annealing of the solid phases. The formation of crystalline gold selenide, including the nanoparticles which are interesting also for materials science, is possible under ambient conditions but it may require stabilizing agents. This was not a target of this research, and we just demonstrated here that, for example, addition of CTAB stabilizes AuSe, although not very effectively. It is likely that CTAB reacts with surfaces of dense liquid intermediates rather than solid AuSe NPs, and it is necessary to find out conditions, possibly the moment for injection of capping ligands, in order to bypass the formation of long-live liquid intermediates.

\section{Conclusions}

The products of the room-temperature reaction of $\mathrm{HAuCl}_{4}$ with $\mathrm{H}_{2} \mathrm{Se}$ and $\mathrm{H}_{2} \mathrm{~S}$ in aqueous solutions depend on relative concentrations of the reactants. Colloidal gold nanoparticles showing plasmon maxima near $530 \mathrm{~nm}$ form at the molar ratios of hydrogen chalcogenide to gold of less than 2 . At the ratios higher than 3, pre-nucleation dense liquid entities of 20-40 $\mathrm{nm}$ in the average hydrodynamic diameter and negative zeta potential grow into submicrometer droplets with time; gradual nucleation and coagulation of disordered gold chalcogenide within the droplets were faster with $\mathrm{H}_{2} \mathrm{~S}$. The soft species can be characterized from UV-vis absorption spectra as having an indirect band gap less than $1 \mathrm{eV}$ in $\mathrm{H}_{2}$ Se media and $2 \mathrm{eV}$ in the case of $\mathrm{H}_{2} \mathrm{~S}$; the gap reduces as the reaction proceededor $\mathrm{H}_{2}$ Se was partially substituted for $\mathrm{H}_{2} \mathrm{~S}$. Surface layers of amorphous gold-selenide AuSe, which form upon drying the reaction media, tend to decompose yielding metallic gold nanoparticles capped with elemental selenium; meanwhile, no metal gold was found in the bulk precipitate using XRD diffraction. As $\mathrm{H}_{2}$ Se was replaced with $\mathrm{H}_{2} \mathrm{~S}$, the products became less stable towards the surface decomposition, and the size of $\mathrm{Au}^{0}$ nanoparticles decreased. UV-vis spectra, XPS, TEM and electron diffraction offer hints that sulfur can partially replace selenium both in dense liquid species and precipitated gold chalcogenide phases. XPS Au $4 \mathrm{f}$ and valence band spectra suggest that AuSe phase contains only one state of $\mathrm{Au}^{+}$with the $\mathrm{BE}$ of $85.4 \mathrm{eV}$. Introduction of a capping ligand (CTAB) somewhat retards decomposition of AuSe. The reaction is an example of the non-classical mechanism of nucleation and crystal growth of inorganic materials involving dense liquid intermediates, which can contribute to the transfer and deposition of gold in the nature. The process can be also employed to prepare, in particular, thin films of $\mathrm{AuSe}_{1-\mathrm{x}} \mathrm{S}_{\mathrm{x}} / \mathrm{Au}^{0}$ nanohybrides with varying contents of $\mathrm{Au}^{0}$ and the band gap of gold chalcogenide.

Supplementary Materials: The following are available online at http:/ / www.mdpi.com/2075-163X/8/11/492/ s1, Figure S1: Hydrodynamic diameters $Z_{\mathrm{av}}$ and zeta-potentials of the colloidal species at various ratios $\mathrm{H}_{2} \mathrm{Se}$ and $\mathrm{H}_{2} \mathrm{~S}$ to determined in 10 min after the mixing, Figure S2: STEM images and corresponding EDS analysis data, Table S1: Atomic ratios and fitting parameters derived from XPS.

Author Contributions: S.V., M.L. and Y.M. conceived and designed the study; S.V. and M.L. performed synthetic, DLS, zeta-potential experiments; S.Z. performed TEM, SAED, EDS experiments, A.K. collected Raman spectra; A.R. and Y.M. conducted XPS measurements; N.M. performed UV-vis experiments; S.V. and Y.M. wrote the paper.

Funding: This research was funded by the Siberian Branch of the Russian Academy of sciences, Program of Interdisciplinary Studies, grant number 64 (project 303).

Conflicts of Interest: The authors declare no conflict of interest. The funding sponsor had no role in the design of the study; in the collection, analyses, or interpretation of data; in the writing of the manuscript, and in the decision to publish the results.

\section{References}

1. Davidson, D.F. Selenium in Some Epithermal Deposits of Antimony, Mercury and Silver and Gold; Geol. Survey Bull: Reston, VA, USA, 1960; Volume 1112-A, pp. 1-16.

2. Barton, M.D. The Ag-Au-S system. Econom. Geol. 1980, 75, 303-316. [CrossRef] 
3. Liu, J.; Liu, J.; Zheng, M.; Liu, X. Au-Se paragenesis in Cambrian stratabound gold deposits, Western Qinling Mountains, China. Int. Geol. Rev. 2000, 42, 1037-1045. [CrossRef]

4. Bindi, L.; Cipriani, C. Structural and physical properties of fischesserite, a rare gold-silver selenide from the De Lamar mine, Owyhee County, Idaho, USA. Can. Mineral. 2004, 42, 1733-1737. [CrossRef]

5. Pal'yanova, G.A.; Kokh, K.A.; Seryotkin, Y.V. Formation of gold and silver sulfides in the system Ag-Au-S. Russ. Geol. Geophys. 2011, 52, 443-449. [CrossRef]

6. Cocker, H.A.; Mauk, J.L.; Rabone, S.D.C. The origin of Ag-Au-S-Se minerals in adularia-sericite epithermal deposits: Constraints from the Broken Hills deposit, Hauraki Goldfield, New Zealand. Miner. Depos. 2013, 48, 249-266. [CrossRef]

7. Seryotkin, Y.V.; Pal'yanova, G.A.; Savva, N.E. Sulfur-selenium isomorphous substitution and morphotropic transition in the $\mathrm{Ag}_{3} \mathrm{Au}(\mathrm{Se}, \mathrm{S})_{2}$ series. Russ. Geol. Geophys. 2013, 54, 646-651. [CrossRef]

8. Palyanova, G.; Karmanov, N.; Savva, N. Sulfidation of native gold. Am. Mineral. 2014, 99, $1095-1103$. [CrossRef]

9. Pal'yanova, G.A.; Kravtsova, R.G.; Zhuravkova, T.V. $\mathrm{Ag}_{2}(\mathrm{~S}, \mathrm{Se})$ solid solutions in the ores of the Rogovik gold-silver deposit (northeastern Russia). Russ. Geol. Geophys. 2015, 56, 1738-1748. [CrossRef]

10. Bindi, L.; Stanley, C.J.; Seryotkin, Y.V.; Bakakin, V.V.; Pal'yanova, G.A.; Kokh, K.A. The crystal structure of uytenbogaardtite, $\mathrm{Ag}_{3} \mathrm{AuS}_{2}$, and its relationships with gold and silver sulfides-selenides. Mineral. Mag. 2016, 80, 1031-1040. [CrossRef]

11. Palyanova, G.A.; Seryotkin, Y.V.; Kokh, K.A.; Bakakin, V.V. Isomorphism and solid solutions among Ag- and Au-selenides. J. Solid State Chem. 2016, 241, 157-163. [CrossRef]

12. Palyanova, G.; Seryotkin, Y.; Kokh, K.; Bakakin, V.V. Sulfur-selenium isomorphous substitution in the $\mathrm{AgAu}(\mathrm{Se}, \mathrm{S})$ series. J. Alloys Compd. 2016, 664, 385-391. [CrossRef]

13. Palyanova, G.A.; Savva, N.E.; Zhuravkova, T.V.; Kolova, E.E. Gold and silver minerals in low-sulfidation ores of the Dzhulietta deposit (northeastern Russia). Russ. Geol. Geophys. 2016, 57, 1171-1190. [CrossRef]

14. Tolstykh, N.; Vymazalová, A.; Tuhý, M.; Shapovalova, M. Conditions of formation of Au-Se-Te mineralization in the Gaching ore occurrence (Maletoivayam ore field), Kamchatka, Russia. Mineral. Mag. 2018, 82, 649-674. [CrossRef]

15. Fang, C.M.; de Groot, R.A.; Wiegers, G.A. Ab initio band structure calculations of the low-temperature phases of $\mathrm{Ag}_{2} \mathrm{Se}, \mathrm{Ag}_{2} \mathrm{Te}$ and $\mathrm{Ag}_{3} \mathrm{AuSe}_{2}$. J. Phys. Chem. Solids 2002, 63, 457-464. [CrossRef]

16. Xiao, C.; Xu, J.; Li, K.; Feng, J.; Yang, J.; Xie, Y. Superionic phase transition in silver chalcogenide nanocrystals realizing optimized thermoelectric performance. J. Am. Chem. Soc. 2012, 134, 4287-4293. [CrossRef] [PubMed]

17. Dalmases, M.; Ibáñez, M.; Torruella, P.; Fernàndez-Altable, V.; López-Conesa, L.; Cadavid, D.; Piveteau, I.; Nachtegaal, M.; Llorca, J.; Ruiz-González, M.L.; et al. Synthesis and thermoelectric properties of noble metal ternary chalcogenide systems of $\mathrm{Ag}-\mathrm{Au}-\mathrm{Se}$ in the forms of alloyed nanoparticles and colloidal nanoheterostructures. Chem. Mater. 2016, 28, 7017-7028. [CrossRef]

18. Liu, M.; Zeng, H.C. General synthetic approach to heterostructured nanocrystals based on noble metals and I-VI, II-VI, and I-III-VI metal chalcogenides. Langmuir 2014, 30, 9838-9849. [CrossRef] [PubMed]

19. Lu, Y.; Li, B.; Zheng, S.; Xu, Y.; Xue, H.; Pang, H. Syntheses and energy storage applications of $M_{x} S_{y}$ $(\mathrm{M}=\mathrm{Cu}, \mathrm{Ag}, \mathrm{Au})$ and their composites: Rechargeable batteries and supercapacitors. Adv. Funct. Mater. 2017, 27, 1703949. [CrossRef]

20. Benning, L.G.; Seward, T.M. Hydrosulphide complexing of Au(I) in hydrothermal solutions from $150-400{ }^{\circ} \mathrm{C}$ and 500-1500 bar. Geochim. Cosmochim. Acta 1996, 60, 1849-1871. [CrossRef]

21. Tagirov, B.R.; Baranova, N.N.; Zotov, A.V.; Schott, J.; Bannykh, L.N. Experimental determination of the stabilities of $\mathrm{Au}_{2} \mathrm{~S}_{(\mathrm{cr})}$ at $25^{\circ} \mathrm{C}$ and $\mathrm{Au}(\mathrm{HS})_{2}{ }^{-}$at $25-250{ }^{\circ} \mathrm{C}$. Geochim. Cosmochim. Acta 2006, 70, 3689-3701. [CrossRef]

22. Pokrovski, G.S.; Tagirov, B.R.; Schott, J.; Hazemanne, J.-L.; Proux, O. A new view on gold speciation in sulfur-bearing hydrothermal fluids from in situ X-ray absorption spectroscopy and quantum-chemical modeling. Geochim. Cosmochim. Acta 2009, 73, 5406-5427. [CrossRef]

23. Zezin, D.Y.; Migdisov, A.A.; Williams-Jones, A.E. The solubility of gold in $\mathrm{H}_{2} \mathrm{O}-\mathrm{H}_{2} \mathrm{~S}$ vapour at elevated temperature and pressure. Geochim. Cosmochim. Acta 2011, 75, 5140-5153. [CrossRef] 
24. Liu, W.; Etschmann, B.; Testemale, D.; Hazemann, J.-L.; Rempel, K.; Müller, H.; Brugger, J. Gold transport in hydrothermal fluids: Competition among the $\mathrm{Cl}^{-}, \mathrm{Br}^{-}, \mathrm{HS}^{-}$and $\mathrm{NH}_{3(\mathrm{aq})}$ ligands. Chem. Geol. 2014, 376, 11-19. [CrossRef]

25. Trigub, A.L.; Tagirov, B.R.; Kvashnina, K.O.; Lafuerz, S.; Filimonova, O.N.; Nickolsky, M.S. Experimental determination of gold speciation in sulfide-rich hydrothermal fluids under a wide range of redox conditions. Chem. Geol. 2017, 471, 52-64. [CrossRef]

26. Ishikawa, K.; Isonaga, T.; Wakita, S.; Suzuki, Y. Structure and electrical properties of $\mathrm{Au}_{2}$ S. Solid State Ion. 1995, 79, 60-66. [CrossRef]

27. Osadchii, E.G.; Rappo, O.A. Determination of standard thermodynamic properties of sulfides in the Ag-Au-S system by means of a solid-state galvanic cell. Am. Mineral. 2004, 89, 1405-1410. [CrossRef]

28. Simon, G.; Essene, E.J. Phase relations among selenides, sulfides, tellurides, and oxides; I, Thermodynamic properties and calculated equilibria. Econ. Geol. 1996, 91, 1183-1208. [CrossRef]

29. Echmaeva, E.A.; Osadchii, E.G. Determination of the thermodynamic properties of compounds in the $\mathrm{Ag}-\mathrm{Au}-\mathrm{Se}$ and Ag-Au-Te systems by the EMF method. Geol. Ore Depos. 2009, 51, 247-258. [CrossRef]

30. Rabenau, A.; Rau, H.; Rosenstein, G. Phase relations in the gold-selenium system. J. Less Common Met. 1971, 24, 291-299. [CrossRef]

31. Rabenau, A.; Schulz, H. The crystal structures of $\alpha$-AuSe and $\beta$-AuSe. J. Less Common Met. 1976, 48, 89-101. [CrossRef]

32. Cretier, J.E.; Wiegers, G.A. The crystal structure of the beta form of gold selenide, $\beta$-AuSe. Mat. Res. Bull. 1973, 8, 1427-1430. [CrossRef]

33. Feng, D.; Taskinen, P. Thermodynamic stability of AuSe at temperature from (400 to 700) K by a solid state galvanic cell. J. Chem. Thermodyn. 2014, 71, 98-102. [CrossRef]

34. Xu, X.L.; Chen, W.K.; Wang, X. Density functional study on adsorption of NO on AuSe (010) surface. Chin. J. Chem. 2008, 26, 107-112. [CrossRef]

35. Wagner, F.E.; Palade, P.; Friedl, J.; Filoti, G.; Wang, N. ${ }^{197}$ Au Mössbauer study of gold selenide, AuSe. J. Phys. Conf. Ser. 2010, 217, 012039. [CrossRef]

36. Ettema, A.R.H.F.; Stegink, T.A.; Haas, C. The valence of $\mathrm{Au}$ in $\mathrm{AuTe}_{2}$ and AuSe studied by X-ray absorption spectroscopy. Solid State Commun. 1994, 90, 211-213. [CrossRef]

37. Lee, W.R.; Jung, D. Electronic structure study of gold selenides. Bull. Korean Chem. Soc. 1999, 20, 147-150.

38. Perry, D.L. Handbook of Inorganic Compounds; CRC Press: Boca Raton, FL, USA, 2011; ISBN 9781439814611.

39. Nath, S.; Ghosh, S.K.; Pal, T. Solution phase evolution of AuSe nanoalloys in Triton X-100 underUV-photoactivation. Chem. Commun. 2004, 966-967. [CrossRef] [PubMed]

40. Prokeš, L.; Kubáček, P.; Peña-Méndez, E.M.; Amato, F.; Conde, J.E.; Alberti, M.; Havel, J. Laser ablation synthesis of gold selenides by using a mass spectrometer as a synthesizer: Laser desorption ionization time-of-flight mass spectrometry. Chem.-Eur. J. 2016, 22, 11261-11268. [CrossRef] [PubMed]

41. Hu, B.; Cheng, R.; Liu, X.; Pan, X.; Kong, F.; Gao, W.; Xu, K.; Tang, B. A nanosensor for in vivo selenol imaging based on the formation of AuSe bonds. Biomaterials 2016, 92, 81-89. [CrossRef] [PubMed]

42. Machogo, L.F.E.; Tetyana, P.; Sithole, R.; Gqoba, S.S.; Phao, N.; Airo, M.; Shumbula, P.M.; Moloto, M.J.; Moloto, N. Unravelling the structural properties of mixed-valence $\alpha$ - and $\beta$-AuSe nanostructures using XRD, TEM and XPS. Appl. Surf. Sci. 2018, 456, 973-979. [CrossRef]

43. Neumann, H.; Yakushev, M.V.; Tomlinson, R.D. Diffusion effects at the Au/p-CuInSe 2 contact studied by XPS. Cryst. Res. Technol. 2003, 38, 676-683. [CrossRef]

44. Haldar, K.K.; Sinha, G.; Lahtinen, J.; Patra, A. Hybrid colloidal Au-CdSe pentapod heterostructures synthesis and their photocatalytic properties. ACS Appl. Mater. Interfaces 2012, 4, 6266-6272. [CrossRef] [PubMed]

45. de la Cueva, L.; Meyns, M.; Bastús, N.G.; Rodríguez-Fernández, J.; Otero, R.; Gallego, J.M.; Alonso, C.; Klinke, C.; Juárez, B.H. Shell or dots-precursor controlled morphology of Au-Se depositson CdSe nanoparticles. Chem. Mater. 2016, 28, 2704-2714. [CrossRef]

46. Jia, J.; Bendounan, A.; Kotresh, H.M.N.; Chaouchi, K.; Sirotti, F.; Sampath, S.; Esaulov, V.A. Selenium adsorption on $\mathrm{Au}(111)$ and $\mathrm{Ag}(111)$ surfaces: Adsorbed seleniumand selenidefilms. J. Phys. Chem. C 2013, 117, 9835-9842. [CrossRef]

47. Ruano, G.; Tosi, E.; Sanchez, E.; Abufager, P.; Martiarena, M.L.; Grizzi, O.; Zampieri, G. Stages of Se adsorption on Au (111): A combined XPS, LEED, TOF-DRS, and DFT study. Surf. Sci. 2017, 662, 113-122. [CrossRef] 
48. Yee, C.K.; Ulman, A.; Ruiz, J.D.; Parikh, A.; White, H.; Rafailovich, M. Alkyl selenide- and alkyl thiolate-functionalized gold nanoparticles: Chain packing and bond nature. Langmuir 2003, 19, 9450-9458. [CrossRef]

49. Hohman, J.N.; Thomas, J.C.; Zhao, Y.; Auluck, H.; Kim, M.; Vijselaar, W.; Kommeren, S.; Terfort, A.; Weiss, P.S. Exchange reactions between alkanethiolates and alkaneselenols on $\mathrm{Au}\{111\}$. J. Am. Chem. Soc. 2014, 136, 8110-8121. [CrossRef] [PubMed]

50. Averitt, R.D.; Sarkar, D.; Halas, N.J. Plasmon resonance shifts of Au-coated $\mathrm{Au}_{2} \mathrm{~S}$ nanoshells: Insight into multicomponent nanoparticle growth. Phys. Rev. Lett. 1997, 78, 4217-4220. [CrossRef]

51. Morris, T.; Copeland, H.; Szulczewski, G. Synthesis and characterization of gold sulfide nanoparticles. Langmuir 2002, 18, 535-539. [CrossRef]

52. Majimel, J.; Bacinello, D.; Durand, E.; Vallee, F.; Treguer-Delapierre, M. Synthesis of hybrid gold-gold sulfide colloidal particles. Langmuir 2008, 24, 4289-4294. [CrossRef] [PubMed]

53. Kuo, C.-L.; Huang, M.H. Hydrothermal synthesis of free-floating $\mathrm{Au}_{2} \mathrm{~S}$ nanoparticle superstructures. J. Phys. Chem. C 2008, 112, 11661-11666. [CrossRef]

54. Schwartzberg, A.M.; Grant, C.D.; van Buuren, T.; Zhang, J.Z. Reduction of $\mathrm{HAuCl}_{4}$ by $\mathrm{Na}_{2} \mathrm{~S}$ revisited: The case for $\mathrm{Au}$ nanoparticle aggregates and against $\mathrm{Au}_{2} \mathrm{~S} / \mathrm{Au}$ core/shell particles. J. Phys. Chem. C 2007, 111, 8892-8901. [CrossRef]

55. Mikhlin, Y.; Likhatski, M.; Karacharov, A.; Zaikovski, V.; Krylov, A. Formation of gold and gold sulfide nanoparticles and mesoscale intermediate structures in the reactions of aqueous $\mathrm{HAuCl}_{4}$ with sulfide and citrate ions. Phys. Chem. Chem. Phys. 2009, 11, 5445-5454. [CrossRef] [PubMed]

56. Mikhlin, Yu.; Likhatski, M.; Tomashevich, Ye.; Romanchenko, A.; Erenburg, S.; Trubina, S. XAS and XPS examination of the Au-S nanostructures produced via the reduction of aqueous gold (III) by sulfide ions. J. Electron Spectrosc. Relat. 2010, 177, 24-29. [CrossRef]

57. Mikhlin, Y.; Karacharov, A.; Likhatski, M.; Podlipskaya, T.; Zizak, I. Direct observation of liquid pre-crystallization intermediates during the reduction of aqueous tetrachloroaurate by sulfide ions. Phys. Chem. Chem. Phys. 2014, 16, 4538-4543. [CrossRef] [PubMed]

58. Likhatski, M.; Karacharov, A.; Kondrasenko, A.; Mikhlin, Y. On a role of liquid intermediates in nucleation of gold sulfide nanoparticles in aqueous media. Faraday Discuss. 2015, 179, 235-245. [CrossRef] [PubMed]

59. Dhayagude, A.C.; Maiti, N.; Debnath, A.K.; Joshi, S.S.; Kapoor, S. Metal nanoparticle catalyzed charge rearrangement in selenourea probed by surface-enhanced Raman scattering. RSC Adv. 2016, 6, 17405-17414. [CrossRef]

60. Mikhlin, Y.L.; Nasluzov, V.A.; Romanchenko, A.S.; Shor, A.M.; Pal'yanova, G.A. XPS and DFT studies of the electronic structures of AgAuS and $\mathrm{Ag}_{3} \mathrm{AuS}_{2}$. J. Alloys Compd. 2014, 617, 314-321. [CrossRef]

61. Mikhlin, Y.L.; Pal'yanova, G.A.; Tomashevich, Y.V.; Vishnyakova, E.A.; Vorobyev, S.A.; Kokh, K.A. XPS and Ag L L $_{3}$-edge XANES characterization of silver- and silver-gold sulfoselenides. J. Phys. Chem. Solids 2018, 116, 292-298. [CrossRef]

62. Hough, R.M.; Noble, R.R.P.; Reich, M. Natural gold nanoparticles. Ore Geol. Rev. 2011, 42, 55-61. [CrossRef]

63. Saunders, J.A.; Burke, M. Formation and aggregation of gold (electrum) nanoparticles in epithermal ores. Minerals 2017, 7, 163. [CrossRef]

(c) 2018 by the authors. Licensee MDPI, Basel, Switzerland. This article is an open access article distributed under the terms and conditions of the Creative Commons Attribution (CC BY) license (http://creativecommons.org/licenses/by/4.0/). 